\title{
Fund Accounting from the Italian Early Tradition to the U.S. GAAP for Governments
}

\section{Aldo Pavan, Bernadette Dessalvi \& Paola Paglietti}

To cite this article: Aldo Pavan, Bernadette Dessalvi \& Paola Paglietti (2017): Fund Accounting from the Italian Early Tradition to the U.S. GAAP for Governments, International Journal of Public Administration, DOI: 10.1080/01900692.2017.1298608

To link to this article: http://dx.doi.org/10.1080/01900692.2017.1298608

$$
\text { 曲 Published online: } 06 \text { Jun } 2017 .
$$

\begin{tabular}{l}
\hline Submit your article to this journal $\square$ \\
\hline$\square$ View related articles $\square$ \\
\hline
\end{tabular}




\title{
Fund Accounting from the Italian Early Tradition to the U.S. GAAP for Governments
}

\author{
Aldo Pavan, Bernadette Dessalvi, and Paola Paglietti \\ Department of Economics and Business Administration, University of Cagliari, Cagliari, Italy
}

\begin{abstract}
Surprising correspondences emerge from the parallel investigation of fund accounting practices in Italian entities until the late nineteenth century and in the contemporary U.S. public sector. The analysis attempts to interpret similarities and differences in light of dissimilar environmental features, and wonders if the Italian tradition could have some explanatory capability on the U.S. present standards. The "fund" concept and its use are strictly similar; they are founded on information needs for governance and internal control. Contemporary requirements for democracy and transparency, and opportunities coming from modern ICT tools bring U.S. organizations to be accountable to the citizenry.
\end{abstract}

\section{KEYWORDS}

Accounting history; Fabio Besta; fund accounting; U.S. GAAP for governments

\section{Introduction}

When facing an unusual practice accounting researchers is generally able to understand its logic, but they could fail at finding its theoretical foundation and actual origin; it may happen that interesting similarities are found with other procedures at different places and times. This is the case of a scholar investigating the "fund accounting" practice which is typically used in the U.S. public sector. It shows preliminary and final accounts of a single organization divided into diverse self-balancing accounts systems related to various activities or organizational units. The "fund" concept was very familiar in the Italian accounting tradition, as revealed by the early authors Angelo Pietra (15501590) and Lodovico Flori (1579-1647); such concept and its practical implementation were particularly investigated, at the end of the nineteenth century, by Fabio Besta (1845-1922). According to the cited authors, this accounting practice had been in use for centuries, particularly in non-business organizations. As noted later in more detail, the fund can express the entire or partial wealth of an organization, and this is, anyhow, the subject of a single set of accounts. Thus, we have as many sets of accounts needed as there are.

Historical studies may derive at first from mere curiosity about past events that can appear unusual and stimulating. From a scientific point of view, in general terms, they are founded on the belief that past and present can be understood if properly located in their periods of time. Present events can be explained by the investigation of the past; similarly, historical phenomena can be enlightened by their more recent evolution. Over time, accounting history was a worthy subject for many scholars in various countries. Very often inquiries were devoted, on the one hand, to the practices and theories in single countries, on the other, to sole bookkeeping techniques and financial statement preparation. In recent times, a so-called new accounting history emerged; it can be viewed as a research stream that can enrich, rather than oppose, the traditional one (Carnegie \& Napier, 2002; Keenan, 1998; Miller, Hopper, \& Laughlin, 1991). It has been claimed that this kind of study needs a broader international view, so it could be ascertained if, and to what extent, accounting innovation arisen in a given environment could have spread in different places and times. Carnegie and Napier (2002) propose an extension of the comparative approach to historical studiesComparative International Accounting History, CIAH -, that investigates both similarities and differences in accounting techniques and theories in various countries (Gernon \& Wallace, 1995; Grew, 1980; Nobes \& Parker, 2000). Building on the asserted social nature of accounting practices (Carnegie \& Napier, 1996; Hopwood, 1983; Napier, 1989), attention is devoted to the features of the environment and the social phenomena that can promote or hinder the rising of the considered accounting innovations (Briston, 1978; Johnson 
\& Caygill, 1971; Scorgie \& Capitanio, 1997; Walton, 1986). Therefore, those kinds of inquiries contemplate accountancy theory and practices as they are located in the social setting in which they emerged and grew. Historical comparative research can be synchronic or parallel, since a given moment or period of time in the past is considered as a reference point. Diffusion studies investigate "how accounting techniques (...) and concepts are transferred from one society to another" (Carnegie \& Napier, 2002, pp. 695-696).

In this research setting, it seems relevant to identify and compare certain accounting practices, related to different times and places, that are equally peculiar and similar each other, so that we can investigate whether the early routines can help in explaining the present ones. ${ }^{1}$ The confirmation of the existence of strong similarities will raise the query of whether a conceivable historical relationship could be found or the two phenomena are not connected at all, and the observed accounting behaviours have completely autonomous origins. In both cases, another query concerns common environmental features that could have shaped, affected, or facilitated those practices. The present research is focused on the above-mentioned comparison and its utility for the better understanding of the contemporary world; it can also be the starting point for a first reasoning on some plausible historical relationships.

This study can be of interest for business scholars as it tries to contribute to the knowledge on fund accounting present practices in the U.S. public sector. The article intends also to deepen the familiarity with the Italian accounting tradition as it is revealed by some early Italian accounting thinkers and particularly by the scientific work, strongly rooted in historical inquiries, of the scholarly master Fabio Besta. $^{2}$ The investigation will be carried out on a comparative basis, and in that way, it can help in strengthening the CIAH stream of research. The present article can also be of interest in that it tries to discover some connections between countries-the U.S.A. and Italy-that most often are segregated from each other in historical accounting studies. Moreover, its interest may lie in that it operates in the little explored field of public sector accounting and accountability evolution (Carnegie \& Napier, 2012).

In light of the aforementioned remarks, the present article investigates whether and to what extent, the early accounting behaviours revealed and explained by Fabio Besta and other Italian thinkers could help in better understanding of the current $U$.
S. fund accounting practices. In more detail, we can now formulate some operational objectives expressed below by the following questions:

Q1, what can be said about the fund accounting concept and its operation in the Italian early practices revealed by Pietra, Flori, and mainly Besta? In which historical settings do they emerge and flourish?

Q2, what are the fundamental features of fund accounting in the U.S. public sector current practices and its environment?

Q3, are we able to identify similarities and differences between the two, and if so, to connect them with the related main socioeconomic features?

Q4, are the results of the above comparison likely to allow the deepening of fund accounting underpinning rationale, so as to significantly help in understanding the current U.S. practices?

The present research is based on a comparative design (Bryman \& Bell, 2007), whereas the situations being compared are placed in different historical and cultural settings. The necessary data come from available documents, related to the investigated phenomena. The work's originality consists of the connected reading of the early Italian texts and the modern North American ones. The books by Pietra and Flori are manuals which provide instructions on how to keep the accounts of the monasteries. In its main work, "Accountancy"-in Italian La Ragioneria (1922)-Fabio Besta presents the main contents and results of his historical studies, which lasted throughout his life, and its general accounting theory deep-rooted in those studies (D’Amico \& Palumbo, 2011; Giannessi, 1980; Perrone, 1986; Pezzoli, 1986). The contemporary American fund accounting practice is regulated by the U.S. Generally Accepted Accounting Principles for State and Local Governments-GAAP for Governments-, whose analysis and interpretation is aided by the reading of the widespread and allembracing presentation made by Warren Ruppel (2013). ${ }^{3}$ These documents are analyzed in their contents, according to the hermeneutic circle concept, by means of which the search for the hidden meaning is based on the constant movement from the understanding of the text as a whole to the clarification of its parts, and vice versa. More precisely, the analysis is carried out by means of the identification, designation, and classification of relevant concepts and techniques, so as to be able to identify meaningful categories and shape grids of analysis 
(Myers, 2009); the subsequent comparison is finalized to recognize similarities and differences. Thereby, it will be possible to reason on correspondences that stay together with various socioeconomic contexts and differences that can, or cannot, be explained by dissimilar environmental features.

\section{The Fund concept and its accounting in the Italian tradition}

The Italian history of accounting is mainly connected with that of the monasteries, located at that time throughout Europe ${ }^{4}$ (Amaduzzi, 2004). In fact, if Luca Pacioli (1445-1517) was a Franciscan friar, the major Italian authors of later centuries were also religious: Angelo Pietra a Benedictine and Lodovico Flori a Jesuit. For centuries, monasteries were centers of spirituality and culture; they also had to meet the needs of large communities of religious citizens and to manage their vast estates and related agricultural production. Unlike what usually happened in small businesses in the Middle Ages and the Renaissance, where the owner was at once the administrator, Angelo Pietra faces the problem of how to control organizations not based on single or few persons and to give account to superiors. The book "Address of Bursars"-in Italian Indirizzo degli Economi (1586) - has an educational aim; in it Pietra explicitly excludes dealing with banks and trade: He only describes the kind of "Double Book" named "Noble Book"-in Italian Libro Nobile-only used by those living from their annuities and namely by monasteries. Finally, he also proposes the extension of the described accounting system to a public entity, such as the Duchy of Mantua. Three inventories have to be used; the first is focused on real estate and related herds; the second is on movable property and its consignees; the last one is on "notes"-in Italian effetti-namely, cash, receivables, payables, and goods in stock. Just the "inventory of notes" is dealt with in the Noble Book; in other words, the subject of the double-entry accounting system is the working capital. Conversely, movable and immovable property are not recorded at all in that book.

Lodovico Flori explicitly continues the work of Pietra; similarly to the latter, he turns his attention to the administration of the religious establishments and, more precisely, to the houses and colleges of the Society of Jesus in the Kingdom of Sicily. In his "Treaty of how to take the home book with its sample"-in Italian Trattato del modo di tenere il libro doppio domestico col suo esemplare (1636; Centorrino, 2008; Quattrone, 2006) - he states that the overall goal of the accounting practice is "to see how our affairs are and to give an account of them". ${ }^{5}$ Flori focuses on the noble book whose upkeep is the responsibility of the "bursar father." The latter updates the ledger monthly, drawing on the daily entries from the journal. Following Pietra's example, Flori proposes an incomplete accounting system, whose subject matter is made up only of the working capital, and where the fixed capital is not taken into account. It is worth mentioning here that Pietra and Flori were practitioners in their religious communities, and consequently, their treatises express both how accounting books had to be kept in their opinion and, most importantly for our purposes, how books were actually kept, at least in some cases.

Besta develops his accounting thinking at the end of the nineteenth century, when the first positivism had been well established. He embraces the experimental approach and founds his accounting theory on historical investigation:

Because only by a large and conscientious observation of facts belonging to different times and places and to organizations of any nature we could induce, with some hope, to grasp the truth. (Besta, 1880, pp. 74-75)

In fact, he spent most of his life in Venice, between his academic chair and the archives of the Most Serene Republic. He studied the early accounting books, as of the end of the fourteenth century, relating to both public and private organizations and investigated their evolution. The economic world he observes is characterized by a relatively slow economic development, small business enterprises, early municipalities, monasteries, and the different administrations of the Italian states. The new and more complex businesses of the late nineteenth and early twentieth century were bigger and more dynamic than those hitherto known as they turned to larger markets; but they continued to be family-owned and to be governed by single individuals. Public administrations had to face new emerging social needs; nevertheless, they still remained organizations where the widespread feeling assigned to public sector duties only related to the making of public goods. Throughout the observed period, accounting records were kept by hand and therefore limited by the lack of skilled operators and by the sheer quantity of article needed. (Amaduzzi, 2004; Coronella, 2007; Palumbo, 2003). 
Fabio Besta's argument builds on the whole entity concept-or organization, in Italian: azienda-that is defined as follows:

the sum of phenomena, businesses or relationships to be managed, connected to an amount of capital that stands alone, or to a single person, or to a family or to any kind of associations, or even only a separate category of those phenomena, businesses or relationships. (Alexander \& Servalli, 2011; Besta, 1922, vol. I, pp. 3-4; Zan, 1994)

With regard to the theory of accounts, an entity is viewed as a wealth to be managed; the self-balancing set of accounts has firstly to disclose the status of this wealth and its variations deriving from operations related both to market exchanges and to internal production processes (Besta, 1922; Bruni, 1996; Ceriani, 2006; Gabrovec Mei, 1995; Landis, Paglietti, \& Pavan, 2012; Paglietti, 2009; Paglietti \& Pavan, 2008).

The "fund" concept has a historical foundation:

The most serious concern of the honest rulers of the public finances, at all times, was to get that the funds were never lacking to pay the costs, which were considered more relevant for the dignity, honor and the welfare of the State. And it seemed that the best way to achieve this intent was to constrain to each of such payments the funds from certain annuities or taxes; this was achieved by guarding those funds in separate cases. (Besta, 1880 , p. 51)

In the Republic of Venice, each case was assigned to an official; payments were authorized even taking into account the expected revenue for the related funding; specific estimates and final accounts were thus kept. It was observed that the large amount of records and checks that they needed was a source of confusion, thus the Senate ruled in 1724 "to study ways, if possible, of reducing to one the many cases relating to public finances." The resolution was not performed due to the Venetian government's fears of a great accumulation of authority in the hands of a single official.

In the second of the three volumes of his main book, Besta works on the advantages coming from the identification and measurement of single funds, each of them considered as a segregated wealth and an accounting entity within the whole organization. He defines the "fund" or "capital fund" as a "complex subject of a system of accounts":

We have many accounting systems; in each of them its complex subject can be regarded as a fund, in its general meaning. When the fund is the whole wealth of the entity, we speak about a comprehensive set of accounts; when the fund is a part of that wealth, the set of accounts is incomplete (...) Such a fund can always be viewed as being made up by elements, one or more, that can be just assets or just liabilities or partially assets and partially liabilities. (Besta, 1922, vol. II, pp. 293-294)

As an entity is a sum of phenomena, but also solely a separate category of those phenomena, its wealth can be regarded as a whole or in its parts. Capital fund is thus defined as the set of items of the whole wealth of the organization or of a part of it. The modern reader could be surprised when considering that the author continues by asserting that "entities that do not have comprehensive accounting systems are much more numerous." In this case, we are talking about incomplete or partial equity systems ${ }^{6}$ that can have a diverse nature and extent. An entity can have just one of them or several at the same time. In general terms, the subject of the set of accounts is the whole wealth; when the organization runs a few incomplete systems, the whole capital fund has to be split up into many segregated funds. This action is framed by the author in a broader technique called "differentiation" of the accounting systems, by which "a complex system is divided into two or more having a lesser extent." In this way, it is possible to have a better understanding of the changing of wealth as a management base:

Differentiation of accounting systems means to divide a complex system into two or more of a lesser extent; such a division is advisable whenever the fund can be divided into two or more funds, each of which has a separate operation and it is opined that the segregation of the sets of accounts can give to management faster and more reliable information on each fund and related operation. Differentiation of accounting systems is very common when the central state, large municipalities, the greatest public bodies and some big private enterprises establish new distinct businesses or autonomous enterprises that utilize separate sets of accounts. (Besta, 1922, vol. II, p. 357)

An interesting class of incomplete accounting records ignores the fixed asset value-e.g., farms and homes; it opens accounts just for money or even stocks, receivables, and payables. Examples of this type, related to the so-called "changeable or working capital," are proposed by Besta explicitly working on previous accounting theories by Pietra and Flori.

While it is always possible to "decompose a given self-balancing set of accounts into two or more smaller systems also self-balancing," it is also possible to put in place the reverse, called "integration." In fact "one could consider it appropriate to merge two or more incomplete sets of accounts that are similar into just one" (Besta, 1922, vol. III, p. 212, vol. II, p. 356). 


\section{Fund accounting in GAAP for governments}

The Anglo-Saxon approach to financial accounting has always been based on equity and its variations (Bailey, 1973; Braden \& Allyn, 1963; Viganò, 1996). The public sector organizations frequently make use of fund accounting (Allen, 2002; Freeman, Lynn, \& Shoulders, 1998; Granof \& Wardlow, 2003; Jones \& Pendlebury, 2000; Kerrigan, 1969; Norvelle, 1994; Pavan \& Reginato, 2012; Ricci, 2006; Rutherford, 1983; Tommasetti, 2008; Vatter, 1947). ${ }^{7}$ This is because the enactment of only one accounting system is believed to be inadequate when dealing with very large organizations, such as central states. The establishment of specific funds can be free or required by law. In the second case, reporting entities with independent accounting systems are defined in terms of identified information needs. It follows that any organization may establish a variable number of funds on the basis of the information considered to be of use; consequently, the whole administration is divided into corresponding self-balancing sets of accounts.

Jones and Pendlebury (2000) present a local authority whose accounting system is divided into a general fund, a municipal housing fund and a fund for the trust management of bequests and donations. The fund accounting technique shows an unprecedented development in the USA. The spread of fund accounting dates back approximately to the 1920s. We are dealing with the administrative apparatus of the today most powerful state in the world that has to face domestic pressure for transparency and involvement-accountability- and external pressure, both competitive and military. The available technical tools are made by the most sophisticated telematics technologies. The theoretical basis of U.S. fund accounting is deep-rooted in the thought of William Joseph Vatter (1947). The fund concept includes the segregation of assets for given purposes, the operations and the service potentials that pertain to those assets. "The emphasis of establishing funds is upon the definition of areas of operation, not upon legal or other form of personality" (p. 39). Two reasons are given in support of fund accounting: the inadequacy of business principles for non-profit organizations, and the need to ensure compliance to restrictions that characterize the public sector administration. This technique was considered by its critics to be a useful tool for internal control purposes, but unable to provide a general overview of the financial position (Anthony, 1980). Accounting standards for the U.S. public sector are currently issued by the GASB who is continuing the work of the previous National Council on Governmental Accounting, NCGA, which published the first collection of accounting principles for municipalities in 1934. The Generally Accepted Accounting Principles-GAAP-for Governments are addressed to states and local governments, various public authorities and so on. Although not directly applicable, they also form the foundation on which standards for the federal level are defined (Tierney, Kearney, Fernandez, \& Green, 2007).

The Concept Statement 1, Objectives of Financial Reporting (GASBCS 1), issued by the GASB in 1987, deals with public environment features, public report users and purposes (Ruppel, 2013). Public environment is characterized by electoral representation, so that the government has its ultimate foundation in the citizenry choice. The relationships between the services rendered and their financing are unfamiliar for those who usually deal with business enterprises, in that the former is based on taxation and is not directly related to the second. In the political process, citizens would like to maximize the received services and minimize tax levying. "These conflicts are handled by politicians whose relatively short terms in public office encourage the use of short-term solutions to long-term problems." In particular, they have an interest in providing services immediately and postponing or deferring payment of any expenses incurred. For this reason, it is appropriate that the accounts show clearly whether the running costs are funded with non-recurring income or long-term debt. In this context, the use of fund accounting, mandated by law or voluntary, is grounded in the need to control the use of resources and to inform the users of financial statements.

The GASBCS 1 identifies three groups of users of financial statements: (a) the citizenry-who are at the same time taxpayers, voters and service recipients-, media, advocacy groups, and public finance researchers; (b) members of elected assemblies, officials of the executive, and oversight bodies; (c) investors, lenders, rating agencies, and financial institutions. The role of citizens and elected assemblies is obviously very peculiar when we compare the public with the business environment; this has relevant implications with the reporting process that is heavily affected by the needs of the users. Due to the peculiar relationships between public organizations and the citizenry, financial reporting in the public sector is heavily characterized by the 
accountability and inter-period equity concepts. The former is strictly related to the right to information that citizens have as voters and taxpayers; it is the leading tool towards efficient and effective operations. The GASBCS 1 describes accountability as the cornerstone of all reporting government activities which have to justify the use of resources. The second indicates that the current generation of citizens should not be able to shift the burden of paying for current-year services to future-year taxpayers. Yet, the particular relationship with the public requires that the information provided by the statements be easily understandable and useful.

The GASB Statement 14 is entitled "The financial reporting entity" (1991). The starting point to identify those that have to give an account is the legal entity. State and local governments exist by themselves, but very often they establish autonomous business units with which they have relationships not necessarily based on shareholding. This makes it clear that the fundamental concept is accountability: The elected officials are accountable to citizens for operations carried out by the government and the connected component units. The report users should be able to distinguish between the results of the two.

The financial reporting entity consists of (a) the primary government, (b) organizations for which the primary government is financially accountable, and (c) other organizations for which the nature and significance of their relationship with the primary government are such that exclusion would cause the reporting entity's financial statements to be misleading or incomplete (Ruppel, 2013).

The definition of fund accounting dates back to the NGCA Statement $1 \rightarrow$

A fund is defined as a fiscal and accounting entity with a self-balancing set of accounts recording cash and other financial resources, together with all related liabilities and residual equities or balances, and changes therein, which are segregated for the purpose of carrying on specific activities or attaining certain objectives in accordance with special regulations, restrictions, or limitations. (Ruppel, 2013, p. 40)

The fund is therefore a separate accounting entity, which does not express an independent legal organization, but is used only for accounting and reporting. It is the subject of a self-balancing set of accounts, which ends with the final state of the fund-balance sheetand an account of fund changes-operating statement. The balance sheet does not always present all the usual items typically present in private sector business financial statements. As we will see in more detail later, when dealing with governmental funds, we do not find both fixed or capital assets and long-term debts. The difference between assets and liabilities is the fund balance.

Fund accounting implements the wealth segregation according to different wealth purposes, so as to allow better control over the collection and proper use of resources. It is an opinion that in this way, it is possible to minimize the risk of overspending and unclear information. According to these principles, in the past, different bank accounts were used, but this practice is considered no longer compatible with the complexity of contemporary administration. We have already said that fund accounting can be free or mandatory, according to laws or regulations related to specific resources: Organizations can have few or many funds, depending on their information sensitivity or control needs. American public sector organizations have been characterized by huge fragmentation and a lack of overall vision for a long time. Thus, in 1999, the GASB Statement no. 34GASBS 34-"Basic financial statements and management's discussion and analysis for state and local governments" was issued. The fund accounting general approach having been confirmed, and it gives an overall picture that is now secured in the government-wide financial statement.

Funds are classified into three major groups: (a) governmental funds; (b) commercial funds-proprietary or business-type funds-; and (c) fiduciary funds. Regarding the former, the general fund is unique to each administration as it holds resources for the general business and, as a residual, all those who have no specific destination. Special revenue funds pertain to distinctive purpose resources; very often they come from the federal or state level of government. Proprietary funds relate to publicly owned enterprises or to internal service activities. Fiduciary funds pertain to resources that are administered on behalf of third parties, such as those relating to the social security treatment of employees.

U.S. fund accounting is founded on two main recognition criteria: the basis of accounting and the measurement focus. The former refers to when a transaction is detected. The modified accrual basis of accounting is a criterion intermediate between the cash and the accrual ones and is of great relevance for the present analysis. It is peculiar to the governmental activity and its features. Its main characteristic is that revenues are recorded when they are "susceptible to accrual," that is when they are both measurable and available to face current outflows. The measurement focus concept, connected to the modified accrual basis of accounting, is related to the flow of current financial resources. The balance- 
sheet of governmental funds typically exposes the currency available in the near future, that means: cash, receivables, inventories, prepaid items, payables, deferred revenues for payments received for future tax levying; as we already said, we do not find fixed assets and long-term liabilities. The operating statement discloses variations in every item of the fund; revenues are made up of increases in net-assets available to spend, expenses by decreases. It is noteworthy here that the

purchase of a capital asset diminishes currency, while a new long-term debt increases it. Proprietary funds are accounted according to the accrual concept; the measurement focus is on the flow of economic resources. The accrual basis of accounting and the related flow of economic resources are used in the government-wide and business-type financial statements. The modified accrual basis and the related flow of current financial resources are used in governmental funds.

\section{Comparative analysis}

The above enquiry shows the Italian tradition of fund accounting until the end of the nineteenth century and the U.S. present practice. With reference to his time, Besta asserts that accounting in modern states is now based on the principles of the money custody separation from the power of disposal, as well as the unity of the treasure; the second then gave rise to the uniqueness of the budget and final accounts. The fund accounting practice is then considered to be outdated; it should perhaps be taken into consideration as being more effective in preventing the natural growth of spending (Besta, 1880). According to Anthony (1980, p. 84),

Until the 1920s, nonbusiness accounting was approximately the same as business accounting (...). In the 1920s, nonbusiness organizations, particularly municipalities, became enamored of the concept that is now called fund accounting, and this led to the schism that persist today.

Within approximately 40 years, the considered practice seems to have moved from one country to another.

In Italy, fund accounting seems to have been used mainly in non-commercial organizations. The economy of the fifteenth to the early twentieth centuries is characterized by a relatively slow development; public and nonbusiness entities are small in size and operate simple economic activities; accounting is oriented toward internal control and accountability to superiors. Available technical means are elementary. Besta's theory summarizes and brings to
Table 1. Italian tradition: Environmental features and conceptual categories.

\begin{tabular}{|c|c|}
\hline Label & Brief description \\
\hline \multicolumn{2}{|l|}{ Environment } \\
\hline Kind of organizations & $\begin{array}{l}\text { Public/nonbusiness organizations: minimal } \\
\text { duties; need for internal control }\end{array}$ \\
\hline Technology & Hand-made accounting \\
\hline Accounting background & $\begin{array}{l}\text { Equity-based accounting system; from } \\
\text { personalistic theory to value accounting }\end{array}$ \\
\hline \multicolumn{2}{|l|}{ Conceptual categories } \\
\hline Entity & $\begin{array}{l}\text { Organization: sum of phenomena connected } \\
\text { to an amount of capital or a separate } \\
\text { category of those phenomena }\end{array}$ \\
\hline Fund & $\begin{array}{l}\text { The whole wealth of an organization- } \\
\text { complete fund-or a part of it-incomplete } \\
\text { fund; the complex subject of a set of } \\
\text { accounts. }\end{array}$ \\
\hline Information need & $\begin{array}{l}\text { Internal control: focus on verification; } \\
\text { accountability to superiors }\end{array}$ \\
\hline $\begin{array}{l}\text { A particular subject of a } \\
\text { set of accounts }\end{array}$ & $\begin{array}{l}\text { Changeable/working fund: Accounts are } \\
\text { opened just to money, stocks, receivables, } \\
\text { and payables. }\end{array}$ \\
\hline $\begin{array}{l}\text { From the whole to the } \\
\text { part, and vice versa }\end{array}$ & $\begin{array}{l}\text { Differentiation: The splitting of a complex } \\
\text { accounting system into two or more ones of } \\
\text { a lesser extent, that is particularly used in } \\
\text { public sector organizations. } \\
\text { Integration: The merging of few similar } \\
\text { incomplete accounting systems; the } \\
\text { integrated fund can derive from the } \\
\text { combination of wealth pertaining to } \\
\text { separate legal entities }\end{array}$ \\
\hline
\end{tabular}

fulfilment a century-old tradition. Emphasis is placed on the fund concept; it is the complex subject of a set of accounts and can be viewed as the whole wealth of an organization or as a part of it; consequently, we can have comprehensive or incomplete accounting systems. An entity can keep under control just the wealth which can be stolen or otherwise be dispersed, that is to say the changeable part of it: particularly money, stocks, receivables, and payables. Via the differentiation technique, the complete accounting systems are split into two or more ones of a lesser extent. Building on the aforementioned assumptions, it is possible to label environmental features and conceptual categories exhibited in Table 1.

The fund accounting technique flourishes in the Anglo-Saxon accounting environment, traditionally focused on the entity's wealth; it shows an unprecedented development in the USA over the last century. The contemporary U.S. setting is politically and economically advanced; public sector organizations are large and complex; they have to face competitive environment and strong pressure for transparency. Advanced ICT tools allow previously unthinkable processing. The accounting theory is rooted in a detailed idea of the public sector that 
considers the nature of its processes, its actors, and the need for both, sound use of resources and accountability to citizens. According to Vatter, the fund concept is founded on the segregation of assets and its service potential. GAAP for Governments are currently issued by the GASB and refer to public authorities, mainly states and local governments. The fund is a fiscal and accounting entity, with a self-balancing set of accounts; it records cash and other financial resources and is segregated for specific activities and objectives. Its use ensures rigorous internal controls, compliance with restrictions that characterize the public sector administration, internal and external accountability. The reporting entity is defined according to both the legal status and the economic autonomy; its utility for decision making and accountability discharging emerged later in the fund accounting practice. The balancesheet of governmental funds shows the flow of current financial resources, namely the currency available in the near future: cash, receivables, inventories, prepaid items, payables, deferred revenues for payments received for future tax levying. The financial statements of the various accounting systems are consolidated into a general one, pertaining to the whole organization. Building on the foregoing assumptions, it is possible to label the

Table 2. GASB, GAAP for governments: Environmental features and conceptual categories.

\begin{tabular}{|c|c|}
\hline Label & Brief description \\
\hline \multicolumn{2}{|l|}{ Environment } \\
\hline Historical period & $\begin{array}{l}\text { From the } 1920 \text { s until today; society and } \\
\text { economy globalization }\end{array}$ \\
\hline Kind of organizations & $\begin{array}{l}\text { Public organizations. Leading world state } \\
\text { after World War II; large duties; pressure for } \\
\text { accountability to the citizenry }\end{array}$ \\
\hline Technology & Advanced telematics \\
\hline Accounting background & $\begin{array}{l}\text { Anglo-Saxon equity approach; public fund } \\
\text { segregation }\end{array}$ \\
\hline \multicolumn{2}{|l|}{ Conceptual categories } \\
\hline Entity & $\begin{array}{l}\text { Reporting entity defined in legal terms and } \\
\text { economic autonomy; useful for decision- } \\
\text { making processes and accountability }\end{array}$ \\
\hline Fund & $\begin{array}{l}\text { A fiscal and accounting entity, with a self- } \\
\text { balancing set of accounts, recording cash } \\
\text { and other financial resources, segregated for } \\
\text { specific activities and objectives }\end{array}$ \\
\hline Information need & $\begin{array}{l}\text { Internal control; accountability to superiors; } \\
\text { accountability to citizens }\end{array}$ \\
\hline $\begin{array}{l}\text { A particular subject of a } \\
\text { set of accounts }\end{array}$ & $\begin{array}{l}\text { The balance-sheet of governmental funds } \\
\text { shows the flow of current financial resources, } \\
\text { namely the currency available in the near } \\
\text { future: cash, receivables, inventories, prepaid } \\
\text { items, payables, deferred revenues for } \\
\text { payments received for future tax levying }\end{array}$ \\
\hline $\begin{array}{l}\text { From the whole to the } \\
\text { part, and vice versa }\end{array}$ & $\begin{array}{l}\text { The financial statements of the various } \\
\text { accounting systems are consolidated into a } \\
\text { general one, pertaining to the whole } \\
\text { organization }\end{array}$ \\
\hline
\end{tabular}

Table 3. Comparison between Italian tradition and GASB, GAAP for governments.

\begin{tabular}{ll}
\hline Label & \multicolumn{1}{c}{ Brief description } \\
\hline $\begin{array}{l}\text { Environment } \\
\text { Historical period }\end{array}$ & $\begin{array}{l}\text { Very dissimilar } \\
\text { Kind of organizations } \\
\text { Technology }\end{array}$ \\
$\begin{array}{l}\text { Accounting background } \\
\text { Conceptual categories }\end{array}$ & Similar \\
Entity & Similar \\
Fund & Similar \\
Information need & Similar, limited to internal \\
& control \\
A particular subject of a set of accounts & Similar \\
From the whole to the part, and vice & Similar, but with different \\
versa & direction \\
\hline
\end{tabular}

environmental features and conceptual categories exhibited in Table 2.

The proposed comparison is not an easy one. The Italian tradition we described has developed over a period of about four centuries, from the late fifteenth to the late 1800s. GAAP for Governments have continued to evolve and to be implemented. Table 3 shows that, except for the accounting background in both cases equity based, very dissimilar environment features coexist with similarities in conceptual categories. The environments observed are very different from the historical, political, technical, and economic points of view. Italian organizations were not large in size and complexity; they acted in environments where the economic and technological development was relatively slow. The United States is the most powerful country in a globalized and constantly evolving world. The U.S. public organizations have thus to react to the internal and external demands for an affluent society, strongly committed to the global scenario. In the first case, technology was still in the "quill"; in the second, they have the most advanced ICT tools at their disposal.

In the periods under observation, the Italian cultural environments had not as yet expressed social curiosity and inquiries about the economic performance of organizations of all kinds; accounting systems could thus ignore external information needs and were only focused on internal control. Claims for accountability occurred in organizations not aimed to profit and in larger firms, but only given to superiors and therefore internal in nature. In monasteries, a need for control emerged limited to the changeable part of the capital. In the Republic of Venice, and in the small public entities of the Middle Ages and the Renaissance, business had to control specific activities, to fund them adequately, to curb the natural tendency to increase spending. 
At the beginning, they put into effect the material separation of monies, and at a later time, they implemented the segregation of accounting systems. The concepts of "fund," "incomplete accounting system," and "fund accounting" are closely linked to the described phenomena. The highly developed $\mathrm{U}$. S. society requires information and transparency. Fund accounting advances for both internal control and external-democratic-accountability purposes. Looking at governmental activities, only the changeable part of the wealth is focused on; in business activities, all the entity's wealth is under observation.

We can say that, although with some differences, in both the U.S. and Italian cases the accounting background was founded on the prominence of the equity notion. With regard to the ideas and techniques specifically under comparison, the definitions and scope of the "organization" and of the "reporting entity" are similar but not identical. Primarily, the relevance of the theoretical concept is different. The former is presented by Besta in the early pages of his book: It is the cornerstone on which what follows are based; the latter is defined by GASB in Statement 14 and discussed by Ruppel in chapter 11: The "reporting entity" is certainly a significant concept, but it is not the starting point of the accounting rules. And yet, in both cases, a need for an entity seems to emerge, to which it is possible to relate a wealth, a set of operations, a management and reporting activity.

In Besta's thinking, fund accounting is useful for management and control purposes, in GAAP standards also, and maybe especially, for reasons related to accountability toward citizens. Besta's notion of a "changeable" fund is here of special interest: The subject of the set of accounts is what we now call the net working capital; this concept was already presented in the sixteenth and seventeenth century by Pietra and Flori. Reasonably, control needs in monasteries were not connected with properties and other fixed assets, while they did not make use of long-term liabilities. GAAP for Governments deal particularly with the recognition of revenues deriving from tax levying. This is a very peculiar topic, unknown in the business world and not dealt with by the considered Italian authors. GASB's standards define later the "measurement focus" concept and apply it to the "accrual" and "modified accrual" environments. The dynamic notions of economic resources flow, in the first case, and flow of current financial resources in the second can be related to those of complete and changeable funds and their variations. Despite the significant difference in the recognition of revenues, the North American relationships between assets and liabilities of the current period seem to be very similar in its own essence to the changeable fund described by Besta as typical of the previous Italian accounting tradition.

\section{Concluding observations}

The present research originated from an initial perception of similarities between the historical accounting Italian tradition attested by Pietra, Flori, and Besta and the contemporary U.S. GAAP for Governments, with regard to fund accounting. This first intuition was compared to the historical theories that investigate the links between accounting and corporate events of different periods and countries, and between these events and the environmental variables in different contexts. Working on the comparison between different cases, some research questions are posed, for instance, about the possible spread in various countries of the accounting innovations that arose originally in one place. In this research, an early accounting practice, dating back to the Middle Ages and the Renaissance, was compared with some U.S. procedures that developed after World War I. To this end, the available documentation was analyzed; specific consideration has been devoted to Besta's seminal book "Accountancy" and to the relevant GASB's statements and standards. Aware of the profound differences in the nature of the two corpuses under inquiry, specific analytical contents have been investigated and examined, always bearing in mind each overall scope. Similarities and differences have emerged from the comparison, and their meaning was explored in light of the environmental features. It is therefore now possible to try to give answers to the specific questions asked at the beginning of the present article.

With regard to the first-Q1-the analysis of Besta's work, in light of the previous ones by Pietra and Flori, reveals that the "fund" concept is pivotal in his thinking and derives from a relevant earlier tradition. The entity's comprehensive fund can be split into two or more partial funds; consequently, complete accounting systems can be "differentiated" into one or several partial systems. A partial fund can be limited merely to the "changeable capital" when this quantity is the only one that is seemingly necessary to be kept under control.

With regard to the second-Q2-the inquiry shows that fund accounting is at the very core of 
U.S. public sector administration, in line with a related tradition of the Anglo-Saxon world. A fund is a fiscal and accounting entity, useful in dealing with information and control needs; it is something segregated from the whole organization. In relatively recent times, an overview is obtained with the definition of the reporting entity and the enactment of the government-wide financial statement. The measurement focus concept, added to the basis of accounting one, allows a fund to be related only to the current financial resources, mainly cash, receivables, inventories, prepaid items, payables, deferred revenues for payments received for future tax levying.

The inquiry shows that the two cases being compared are related to very different environments, so that the arisen similarities and differences have to be properly interpreted-Q3. The analyzed corpuses are very different; the first presents the Italian tradition that has developed over four centuries; the second presents an evolving body of accounting standards, pertinent to the contemporary U.S. public sector. In both cases, we can observe a common regulatory purpose about the accounting practice. There is no doubt that the identified concepts and techniques are so close as to be considered variants of the same idea; they can be considered as part of an evolutionary perspective. It is the case when dealing with the "fund" notion. In Besta, it is firstly considered in the broader extent and secondly differentiated; in GAAP for Governments, it is originally viewed in a narrower size and then consolidated. In both cases, it is a wealth that can be identified and segregated in large organizations and has to be well known for managerial and control purposes. Similarly, the changeable fund and the flow of current financial resources can be easily related to a unique idea. In both cases, the only subject of the set of accounts is a kind of net working capital, as it is the only quantity in which people are interested in knowing its status and variations.

About the last question-Q4-, the conceptual connections lead us to believe that the deepening of the Italian accounting tradition and mostly of Besta's theories has a significant explanatory nature about the described contemporary U.S. practices. In both cases, limited to the information needs of government and control, reasons of the same nature suggest the adoption of fund accounting and its diverse shaping in nonbusiness and public sector organizations. Environmental differences seem able to explain dissimilarities, such as the prevailing differentiation in Besta and integration in GAAP, the different degree of detail, and mainly the evolution toward the external-democratic-accountability.

In light of the above answers, the "fund accounting" practices of the Italian tradition and the contemporary U.S. public sector show surprising similarities. They may have been formed in a completely unconnected way, in response to similar needs to curb the increase in spending and to protect the entity's wealth. In the U.S. case, concepts and techniques have evolved, according to different environment features. We cannot even exclude, however, that there could have been a historical continuity between the early Italian and the present North American practices. Bearing in mind that double-entry bookkeeping originated primarily in Italy and later spread all over the world, a historical relationship could have been occurring mainly through the accounting routine, but also via the international circulation of the works by Pietra, Flori and Besta, or their summaries and other works in different languages which got lost. ${ }^{8}$ It is a captivating hypothesis to be investigated in future research.

\section{Notes}

1. Correspondingly, in a recent article on the IASB/ FASB accounting standards, Macve (2010) invokes the authority of Luca Pacioli in support of his theses concerning the objectives of financial accounting.

2. The academic relevance of the latter has recently been proposed again to international audiences by Sargiacomo, Servalli, and Andrei (2012).

3. Ruppel's book is updated every year and is generally considered as a valuable source of information on the topic (Hou, 2003; Mulazzani, 2002; Pozzoli, 2005; Van Lent, 2012).

4. In dealing with the fall of Rome in 476, Jacob Soll says "its heir, the Catholic Church and its massive monasteries, continued to administer land, goods, and payments through basic accounting and auditing." (2014, p. 7).

5. According to B.S. Yamey "Lodovico Flori was the author of one of the most interesting and sophisticated of the early treatises on bookkeeping and accounts" (2012, p. 13).

6. Again on the topic "The application of the double entry method to incomplete equity systems of every kind is at present, and it was in the past, a very common practice of the bookkeeping art. In fact, I dare say that, except for collective enterprises, very few business entities applied or apply at present that method to complete equity systems" (Besta, 1922, vol. III, p. 144).

7. The fund accounting practice in England was known by Besta who writes "revenues were divided into three funds the Aggregate fund, the General fund and the South sea fund, each one aimed to specific outlay 
categories; balances of the three funds, after the payments of the related expenses, had to be collected in a fourth fund aimed at extinguishing the debts (Sinking fund)." As mentioned earlier, public monies were gathered "in 1816 only in a fund called consolidated fund, and the unification was accomplished when the treasury services were delegated to the Bank" (Besta, 1880, pp. 57-58).

8. The hypothesis is consistent with that given by Besta about the first spread of the double-entry method (vol III, pp. 360-391), duly cited by Sargiacomo et al. (2012, p. 256).

\section{References}

Alexander, D., \& Servalli, S. (2011). Economia aziendale and financial evaluation in Italy, Some contradiction and insights. Accounting History, 16, 291-312. doi:10.1177/1032373211407052

Allen, T. L. (2002). Public accountability and government financial reporting. Journal on Budgeting, 2(supplement 1), 11-33.

Amaduzzi, A. (2004). Storia della Ragioneria. Percorsi di ricerca tra aziende e contabilità, dottrine e professioni. Milano, Italia: Giuffrè.

Anthony, R. N. (1980, May-June). Making sense of nonbusiness accounting. Harvard Business Review, 58, 83-93.

Bailey, F. (1973). Current practice in company accounts. London, UK: Haymarket Publishing.

Besta, F. (1880). Prolusione letta nella solenne apertura degli studi per l'anno scolastico 1880-81 alla R. Scuola Superiore di Commercio in Venezia. Venezia, Italia: Tipografia dell'Istituto Colletti.

Besta, F. (1922). La Ragioneria vol. I - III, ristampa della $2^{\circ}$ edizione, riveduta e ampliata col concorso dei proff. $V$. Alfieri, C. Ghidiglia e P. Rigobon. Milano, Italia: Vallardi.

Braden, A. D., \& Allyn, R. G. (1963). Accounting principles. U.S: D. Van Nostrand Company.

Briston, R. J. (1978). The evolution of accounting in development countries. International Journal of Accounting, 14, 105-120.

Bruni, G. (1996). La 'Ragioneria scientifica' nel pensiero di Fabio Besta e nelle successive tendenze ed evoluzioni. Rivista Italiana Di Ragioneria E Di Economia Aziendale, 9(10), 538-543.

Bryman, A., \& Bell, E. (2007). Business research methods. Oxford, UK: Oxford University Press.

Carnegie, G. D., \& Napier, C. J. (1996). Critical and interpretive histories: Insights into accounting's present and future through its past. Accounting, Auditing \& Accountability Journal, 9, 7-39. doi:10.1108/09513579610121956

Carnegie, G. D., \& Napier, C. J. (2002). Exploring comparative international accounting history. Accounting, Auditing \& Accountability Journal, 15, 689-718. doi:10.1108/ 09513570210448966

Carnegie, G. D., \& Napier, C. J. (2012). Accounting's past, present and future: The unifying power of history. Accounting, Auditing \& Accountability Journal, 25, 328389. doi:10.1108/09513571211198782

Centorrino, G. (2008). Il trattato di Padre Ludovico Flori. Analisi del contenuto e trasposizione in linguaggio contemporaneo. Roma, Italia: Aracne.
Ceriani, G. (2006). Il sistema contabile patrimoniale nell'impostazione di Fabio Besta, nella variante corrente ed in quella nord-americana. Contabilità E Cultura Aziendale, 6, 33-62.

Coronella, S. (2007). La ragioneria in Italia nella seconda metà del XIX secolo. Profili teorici e proposte applicative. Milano, Italia: Giuffrè.

D’Amico, L., \& Palumbo, R. (2011). Fabio Besta e la nascita della Ragioneria moderna. Contabilità E Cultura Aziendale, 11, 36-67.

Flori, L. (1636). Trattato del modo di tenere il libro doppio domestico col suo esemplare. Palermo, Italia: Decio Cirillo.

Freeman, R. J., Lynn, E. S., \& Shoulders, C. D. (1998). Governmental and nonprofit accounting: Theory and practice. Englewood Cliffs, NJ: Prentice-Hall.

Gabrovec Mei, O. (1995). Sistemi contabili e strutture del conto del risultato economico. Padova, Italia: CEDAM.

GASB, Governmental Accounting Standard Board. (1991). Statement 14: The financial reporting entity. Norwalk. USA: Financial Accounting Foundation.

Gernon, H., \& Wallace, R. S. O. (1995). International accounting research: A review of its ecology, contending theories and methodologies. Journal of Accounting Literature, 14, 54-106.

Giannessi, E. (1980). I precursori in economia aziendale (4th ed.). Milano, Italia: Giuffrè.

Granof, M. H., \& Wardlow, P. S. (2003). Core contents of government and not-for-profit accounting. Hoboken, N.J: Wiley.

Grew, R. (1980). The case for comparative histories. The American Historical Review, 85, 763-778. doi:10.2307/ 1868871

Hopwood, A. G. (1983). On trying to study accounting in the contexts in which it operates. Accounting Organizations and Society, 8, 287-305. doi:10.1016/0361-3682(83)90035-1

Hou, Y. (2003). What stabilizes state general fund expenditures in downturn years: Budget stabilization fund or general fund unreserved undesignated balance? Public Budgeting \& Finance, 23, 64-91. doi:10.1111/15405850.2303004

Johnson, T. J., \& Caygill, M. (1971). The development of accounting links in the Commonwealth. Accounting and Business Research, 1, 155-173. doi:10.1080/ 00014788.1971.9728562

Jones, R., \& Pendlebury, M. (2000). Public sector accounting. Harlow, UK: Pearson Education Limited.

Keenan, M. G. (1998). A defence of 'traditional' accounting history research methodology. Critical Perspectives on Accounting, 9, 641-666. doi:10.1006/cpac.1998.0273

Kerrigan, H. D. (1969). Fund accounting. U.S.: McGrawHill.

Landis, C., Paglietti, P., \& Pavan, A. (2012). I sistemi di controllo interno e la costrizione degli atti amministrativi nella scuola di Fabio Besta. Alcune riflessioni di carattere comparative. Contabilità E Cultura Aziendale, XII, 96-126.

Macve, R. (2010). The case for deprival value. Abacus, 46, 111-119. doi:10.1111/abac.2010.46.issue-1

Miller, P., Hopper, T., \& Laughlin, R. (1991). The new accounting history: An introduction. Accounting, Oraganizations and Society, 16, 395-403. doi:10.1016/ 0361-3682(91)90036-E 
Mulazzani, M. (2002). Dalla contabilità finanziaria alla contabilità economico-patrimoniale negli enti locali. Milano, Italia: FrancoAngeli.

Myers, D. (2009). Qualitative research in business and management. UK: SAGE.

Napier, C. (1989). Research directions in accounting history. The British Accounting Review, 21, 237-254. doi:10.1016/ 0890-8389(89)90095-4

Nobes, C., \& Parker, R. (2000). Comparative international accounting (6th ed.). Harlow, UK: Financial Times/ Prentice Hall.

Norvelle, J. W. (1994). Introduction to fund accounting. USA: Thoth Books.

Paglietti, P. (2009). Exploring the role of accounting history following the adoption of IFRS in Europe. The case of Italy. De Computis, 11, 83-115.

Paglietti, P., \& Pavan, A. (2008). La teoria contabile di Fabio Besta alla luce del modello di bilancio IASB. Contabilità $E$ Cultura Aziendale, 8, 7-27.

Palumbo, R. (2003). Profili della teoria del valore negli studi di ragioneria. Dall'affermazione del paradigma bestano alla definizione delle 'tendenze nuove'. Milano, Italia: Giappichelli.

Pavan, A., \& Reginato, E. (2012). Programmazione e controllo nelle amministrazioni pubbliche. Milano, Italia: Giuffrè.

Perrone, E. (1986). La dottrina di Fabio Besta nell'evoluzione della ragioneria. Siena, Italia: Quaderni dell'Istituto di Ragioneria dell'Università.

Pezzoli, S. (1986). Profili di storia della ragioneria. Padova, Italia: Cedam.

Pietra, A. (1586). Indirizzo degli economi. Mantova, Italia: Francesco Osanna..

Pozzoli, M. (2005). Principi contabili ed enti locali: La prospettiva internazionale. Milano, Italia: FrancoAngeli.

Quattrone, P. (2006). Il trattato del modo di tenere il libro doppio domestico col suo esemplare di Lodovico Flori. In C. Lipari (Ed.), Autori di Ragioneria a Palermo, XVII-XVIII secolo (pp. 37-71). Palero, Italia: University of Palermo.

Ricci, P. (2006). Metodologie e strumenti per la riduzione della spesa nelle amministrazioni pubbliche. Milano, Italia: Franco Angeli.
Ruppel, W. (2013). GAAP for governments. New York, NY: Wiley.

Rutherford, B. A. (1983). Financial reporting in the public sector. London, UK: Butteworths.

Sargiacomo, M., Servalli, S., \& Andrei, P. (2012). Fabio Besta: Accounting thinker and accounting history pioneer. Accounting History Review, 22, 249-267. doi:10.1080/21552851.2012.728904

Scorgie, M. E., \& Capitanio, C. (1997). Transportation of double entry bookkeeping to early New South Wales. Accounting History, 2, 105-111. doi:10.1177/ 103237329700200207

Soll, J. (2014). The reckoning. New York, NY: Basic Books.

Tierney, C. E., Kearney, E. F., Fernandez, R., \& Green, J. W. (2007). Federal accounting handbook. Policies, standards, procedures, practices. New York, NY: Wiley.

Tommasetti, A. (2008). I sistemi contabili nelle amministrazioni pubbliche. Una prospettiva internazionale. Padova, Italia: Cedam.

Van Lent, L. (2012). Discussion of the influence of elections on the accounting choices of governmental entities. Journal of Accounting Research, 50, 477-494. doi:10.1111/joar.2012.50.issue-2

Vatter, W. J. (1947). The fund theory of accounting and its implications for financial reports. Chicago, IL: University of Chicago.

Viganò, E. (1996). L'economia Aziendale e la ragioneria. Evoluzione, prospettive internazionali. Padova, Italia: Cedam.

Walton, P. (1986). The export of British accounting legislation to Commonwealth countries. Accounting and Business Research, 16, 353-357. doi:10.1080/ 00014788.1986.9729335

Yamey, B. S. (2012). Personal accounts, account books and their probative value: Historical notes, c. 1200 to c. 1800. The Accounting Historians Journal, 39, 1-26.

Zan, L. (1994). Towards a history of accounting histories. Perspectives from the Italian tradition. European Accounting Review, 3, 255-307. doi:10.1080/ 09638189400000021 